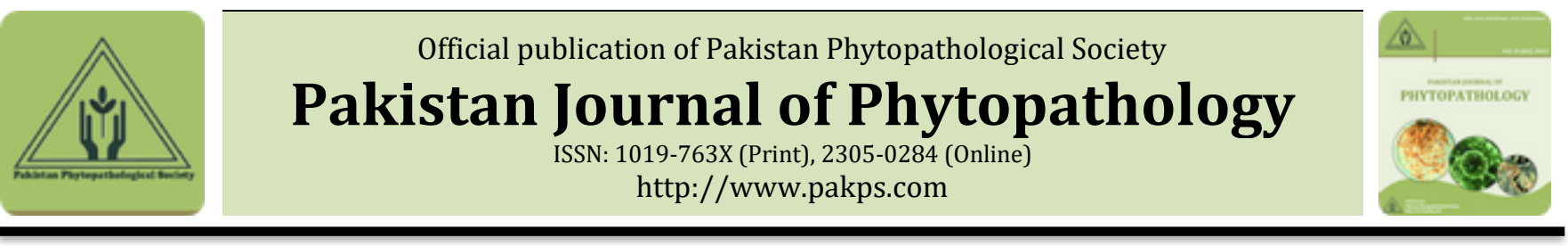

\title{
EFFECT OF URDBEAN LEAF CRINKLE VIRUS ON BIOCHEMICAL PROPERTIES OF URDBEAN PLANTS IN RELATION TO WHITEFLY AND ENVIRONMENTAL FACTORS
}

\author{
aYasir Iftikhar, a,bMustansar Mubeen*, cQaiser Shakeel, aHafiz M. A. Saeed, aSonum Bashir, aAshara Sajid, \\ aFaheema Bakhtawar, bAqleem Abbas, bShehzad Iqbal \\ a Department of Plant Pathology, College of Agriculture, University of Sargodha, Sargodha, 40100, Pakistan. \\ b State Key Laboratory of Agricultural Microbiology and Provincial Key Laboratory of Plant Pathology of Hubei Province, \\ College of Plant Science and Technology, Huazhong Agricultural University, Wuhan 430070, Hubei, P.R. China. \\ c Department of Plant Pathology, University College of Agriculture and Environmental Sciences, The Islamia University of \\ Bahawalpur, Bahawalpur, Pakistan.
}

\section{A B S T R A C T}

The urd bean (Vigna mungo (L) Hepper) is an important pulse crop produced worldwide. The Urdbean Leaf Crinkle Virus (ULCV) is a widespread disease of urdbean in Pakistan because it causes extensive damage to its yield. ULCV is infected by two most important pest, whitefly, and beetles. The environmental factors also play a vital role in the spread of disease. Among the environmental factors, the relative humidity and temperature have a significant impact on the ULCV disease. Moreover, the relationship between environmental factors, ULCV and whitefly populations is significant and shows non-remarkable interactions. It has been found that the total chlorophyll of the infected plants has increased on an average of 18.47 (12.3-24.4) which is significantly different from healthy plants. Moreover, the photosynthetic rate of the infected urdbean genotype has also increased on an average of 5.36 (4.36-8.97) compared to healthy plants $2.20(1.42-2.95)$. The total phenol in the infected plants after the ULCV infection was 82.19 (74.3285.18) milligrams $/ \mathrm{kg}$ which increased to 102.5 (94.2-111.5) milligrams $/ \mathrm{kg}$ of fresh weight. In conclusion, the infected plants have higher photosynthetic rate, chlorophyll contents and total phenol content than the healthy plants. All urdbean genotypes were found to be susceptible to ULCV. Furthermore, both environmental factors and whitefly populations have a positive impact on the ULCV disease.

Keywords: Urdbean genotypes, ULCV, environmental factors, vectors, Physiology

\section{INTRODUCTION}

The pulses are a rich source of proteins and are therefore known as "the meat of the poor". The protein content of various legumes is between $17-24 \%$, about 2 3 times that of cereals (Ashfaq et al., 2010). Urdbean (Vigna mungo (L) Hepper) belonging to the family of Leguminosae, also known as Heck. It originated in the subcontinent and now grows on almost all continents, namely Europe, Australia, Asia, Africa and the United States. In Pakistan, it covers an area of 209,000 hectares,

Submitted: July 21, 2020.

Revised: December 15, 2020.

Accepted for Publication: December 15, 2020

* Corresponding Author:

Email: mustansar01@yahoo.com

(C) 2017 Pak. J. Phytopathol. All rights reserved. produces 102,000 tons of grain per year and produces $6.4 \%$ of its annual output (Ashfaq et al., 2014). The low yield of the harvest is due to some biological and biological components. These ingredients lead to various biochemistry and physiological modifications of plants (Arooj et al., 2019). Among these components, biological components cause a severe economic loss of production in the world's legume-growing regions (Montasser et al., 2012). The urdbean leaf crinkle virus (ULCV) causes high losses and destroys the entire urdbean crop depending on the season and genotype (Reddy et al., 2005). Urdbean leaf crinkle disease is a serious urdbean disease in Pakistan which is a common disease in urdbean (Ilyas et al., 1992). The ULCV is a single standard RNA genome in a range of $25-30 \mathrm{~nm}$. ULCV was first reported from India (Cohan and Kalia, 1972). 
Severe attacks of ULCV result in losses of up to $67-100 \%$ (Bashir and Mansoor, 2006). The severity and incidence of ULCV depend on the environmental factors and the genotype of the host plant (Ashfaq et al., 2007). The main symptoms of the disease are extreme bending, crawling, puking, and leaf rugosity decreased plant growth and the deformity of the flower parts. Pod formation and fertility of the diseased plant (Nene, 1972 ) is greatly reduced. During seeds infections, crop production reduces to $35-81 \%$ (Bashir et al., 1991). ULCV is usually spread through insect vectors and seeds (Kadian, 1980). ULCV transmitted by seeds at a rate of 2.7-46\% (Bhardwaj and Dubey, 2008). ULCV disease reduces the weight of seeds/pods, pods/plants, produce/plants, 100 grains associated with their healthy plants. In recent years, researchers have done significant work to identify the potential control of the disease (Binyamin et al., 2011). Weather affects plant disease epidemic (Mubeen et al., 2017) is an important factor. Moreover, baseline information is required to create basic and reliable disease prediction systems to understand weather and climate conditions. Limited work related to the environmental conditions that help to spread ULCV disease has been completed. The impact of environmental conditions and their diversity related to the development and spread of diseases is not explained in a quantitative manner (Ashfaq et al., 2008). The development of the disease depends on the epidemiological factor, which is not fully tested or evaluated, with the continuing extensive damage caused by primary infections, infected seeds and pod settings and the severity of the disease. A large part of the physiological changes tested can be the indirect effects of viral infections due to various metabolic processes and interventions in nutrition, water transport and various substances. Minerals play an important role in certain diseases, either altering the physiological processes of plants and disrupting the infection process or adapting or destroying plant genotypes (Luria et al., 1978). The present study was conducted to determine the impact of ULCV and whitefly on the physiological changes that occur on the affected parts of the urdbean, because of the importance of the virus's impact on the urdbean genotypes.

\section{MATERIALS AND METHODS}

Plant materials: The samples were collected from healthy and infected fields of the research area of the Department of Plant Pathology, College of Agriculture, the University of Sargodha, Pakistan. Healthy and diseased leaves of tomato were collected for the estimation of Photosynthetic rate, chlorophyll contents, total soluble phenolic and total phenolic contents relation to environmental factors.

Estimation of Photosynthetic rate: The concentration of $\mathrm{CO}_{2}$ in gas passing through the chamber was measured by using an IRGA (Infra-Red Gas Analyzer). For this purpose, six urdbean plants were selected randomly and observed the photosynthesis rate of healthy and infected leaves with the help of IRGA. Photosynthesis rate was observed with the prevalence of the disease.

Estimation of chlorophyll: The total chlorophyll contents were observed in healthy and diseased samples through the chlorophyll meter. The samples were collected from the experimental plot, five urdbean plants were randomly selected and picked healthy and diseased leaves samples (Bhaktavatsalam et al., 1983). Marked the fresh samples and packed the sample in polythene packets. The total chlorophyll contents were measured of fresh samples by using chlorophyll meter then mean was calculated of observed healthy and disease samples.

Estimation of total soluble phenolic: The total soluble solids from both the infected and healthy urdbean leaves were collected from the research fields as.

1. The urdbean Leaves were washed with distilled water to remove dust particles, shade dried and ground.

2. Next, the plant products were extracted by dipping in the absolute methanol for seven days.

3. The methanol extract was then concentrated to dryness under reduced pressure using rotary evaporated and then stored in the refrigerator at $-4^{\circ} \mathrm{C}$ until used for analysis.

Estimation of total phenolic: For the measurement of total phenolic contents protocol of Chaovanalikit and Wrolstad (2004) was followed. Briefly about $0.5 \mathrm{~g}$ plant extracts were dissolved in $0.5 \mathrm{ml}$ Folin-Ciocalteu (F-C) phenol reagent and $7.5 \mathrm{~mL}$ of distilled water was added. The mixture was incubated at room temperature for $10 \mathrm{~min}$. after incubation, $1.5 \mathrm{~mL}(20 \%)$ of $\mathrm{Na} 2 \mathrm{CO} 3(\mathrm{w} / \mathrm{v})$ was added to the mixture. Then the mixture was heated on the water bath for $20 \mathrm{~min}$ at $40^{\circ} \mathrm{C}$ and cooled immediately in an ice bath and the absolute absorbance noted at $755 \mathrm{~nm}$ and total phenolic contents were calculated based on the calibration curve for gallic acid $(20-200 \mathrm{mg} / \mathrm{L}, \mathrm{R} 2=0.998)$ and the results were expressed as acid equivalent (GAE) per dry matter. 
Correlation of Environmental Factors: Environmental factors data were collected every two weeks from the weather station installed in the In-service Agriculture Institute Sargodha. The environmental factors include are maximum and minimum temperature and relative humidity.

\section{STATISTICAL ANALYSIS}

The data was correlated concerning various environmental factors by using "Microsoft excel correlation commands. Moreover, the mean population density of whiteflies was also calculated.

\section{RESULTS}

Eight ( $\mathrm{V}_{1}$ Arooj, $\mathrm{V}_{2}$ 6065-3, $\mathrm{V}_{3}$ 6036-21, $\mathrm{V}_{4}$ 4eM-716, $\mathrm{V}_{5}$ ES-I, $V_{6}$ M-95, $V_{7}$ ARRIM-08 and $V_{8}$ ARRIM-16) genotypes of urdbean were planted under field conditions. After the emergence of seedlings, the whiteflies started to land, and the process of infestation continued until the plants reach maturity. The leaves were curled, and leaves showed rugosity. Infected plants are counted, and the percentage of disease progress is recorded regularly. The results clearly indicated that the initial period of seven weeks, urdbean crop is highly serious for the spread and development of ULCV. Field environment was highly favorable for natural spread of the disease due to high vector population as examined later and buildup of inoculums potential of virus from germination. It was also examined that there were minimum chances of disease escape except due to changes in environmental factors. The data presented in (Figure 1) showed that whitefly density on urdbean genotypes ranged between 1-4 adult/plant. Maximum whitefly density was observed on M-95 (3.75) which showed significantly different from all other urdbean genotypes. Minimum whitefly density was observed on Arooj (1.83) and ARRIM-16 (1.82) which are not statistically different followed by 6036-21 (3.08), 6065-3 (2.66), that also gave non-significant difference among themselves. ES-I (3.34) was significantly different from all other urdbean genotypes.

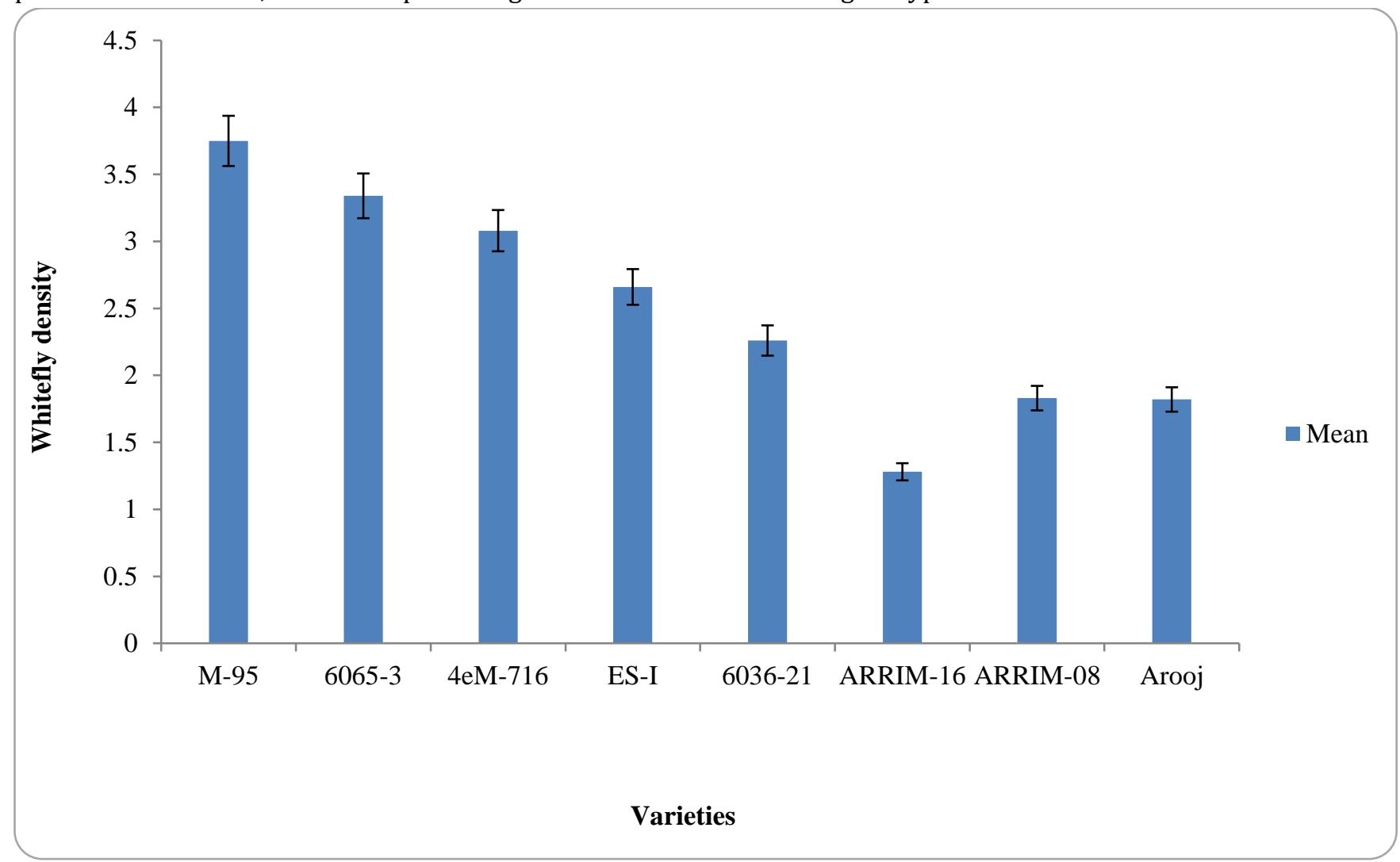

Figure 1. Population density of whitefly on urdbean genotypes

Effect of whitefly population and maximum Maximum whitefly density was found at $24.6^{\circ} \mathrm{C}-26.5^{\circ} \mathrm{C}$. temperature on the urdbean genotypes: Negative The relationship was best explained by linear regression correlation was found between whitefly density and models as indicated by $0.95,0.93,0.95$ and $0.95 \mathrm{r}$ values, maximum temperature on genotypes of urdbean. respectively (Figure 2). 


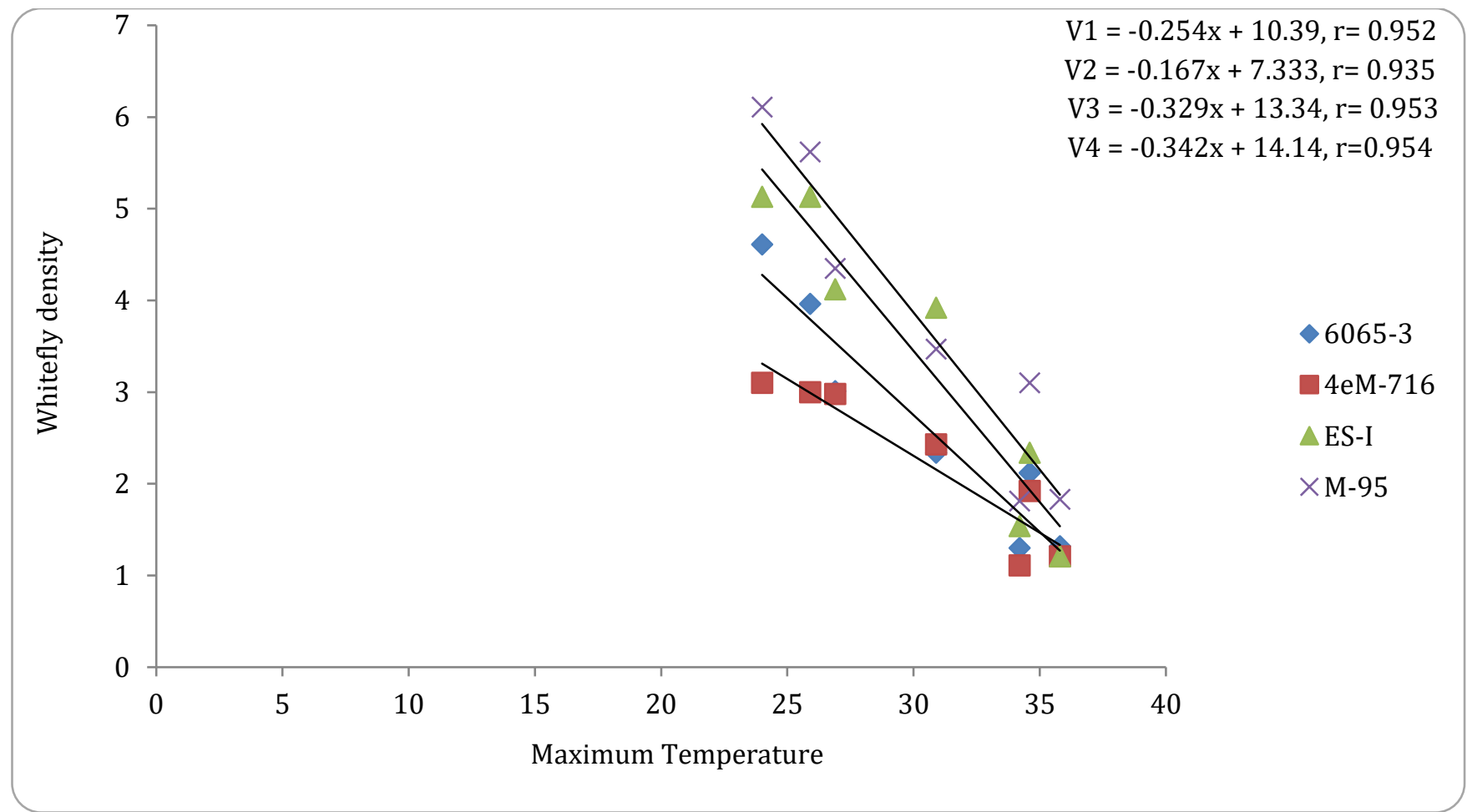

Figure 2. Relationship of maximum temperature with whitefly density recorded on urdbean genotypes

Effect of whitefly population and minimum and minimum temperature on genotypes of urdbean temperature on the urdbean genotypes: Negative was recorded. Highest whitefly population density correlation between the whitefly population density was recorded at $7^{\circ} \mathrm{C}-14^{\circ} \mathrm{C}$ (Figure 3 ).

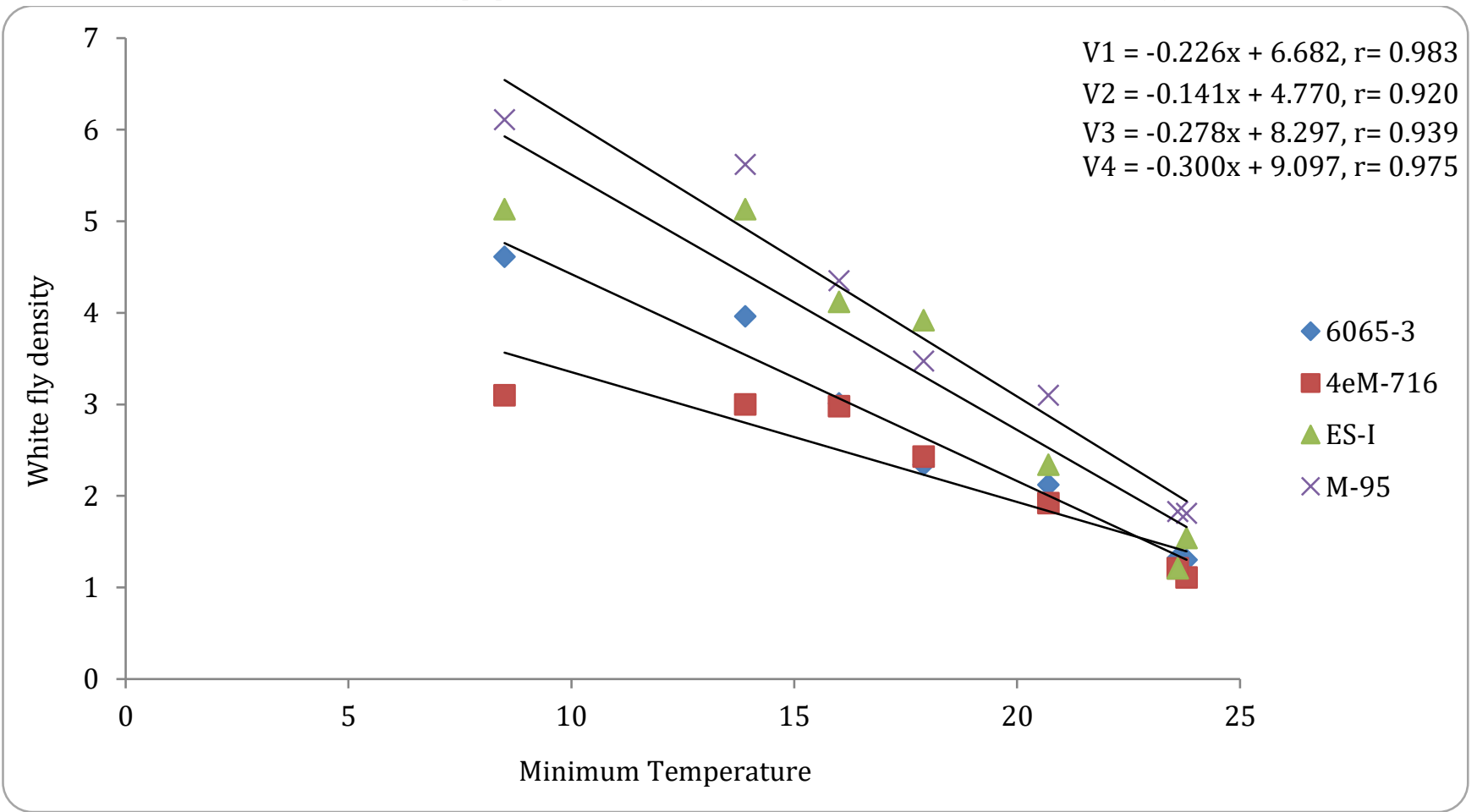

Figure 3. Relationship of minimum temperature with whitefly density recorded on urdbean genotypes

Effect of relative humidity and the whitefly population on the urdbean genotypes: Negative correlation between whitefly density and relative humidity on genotypes of urdbean was recorded (Figure 4). 


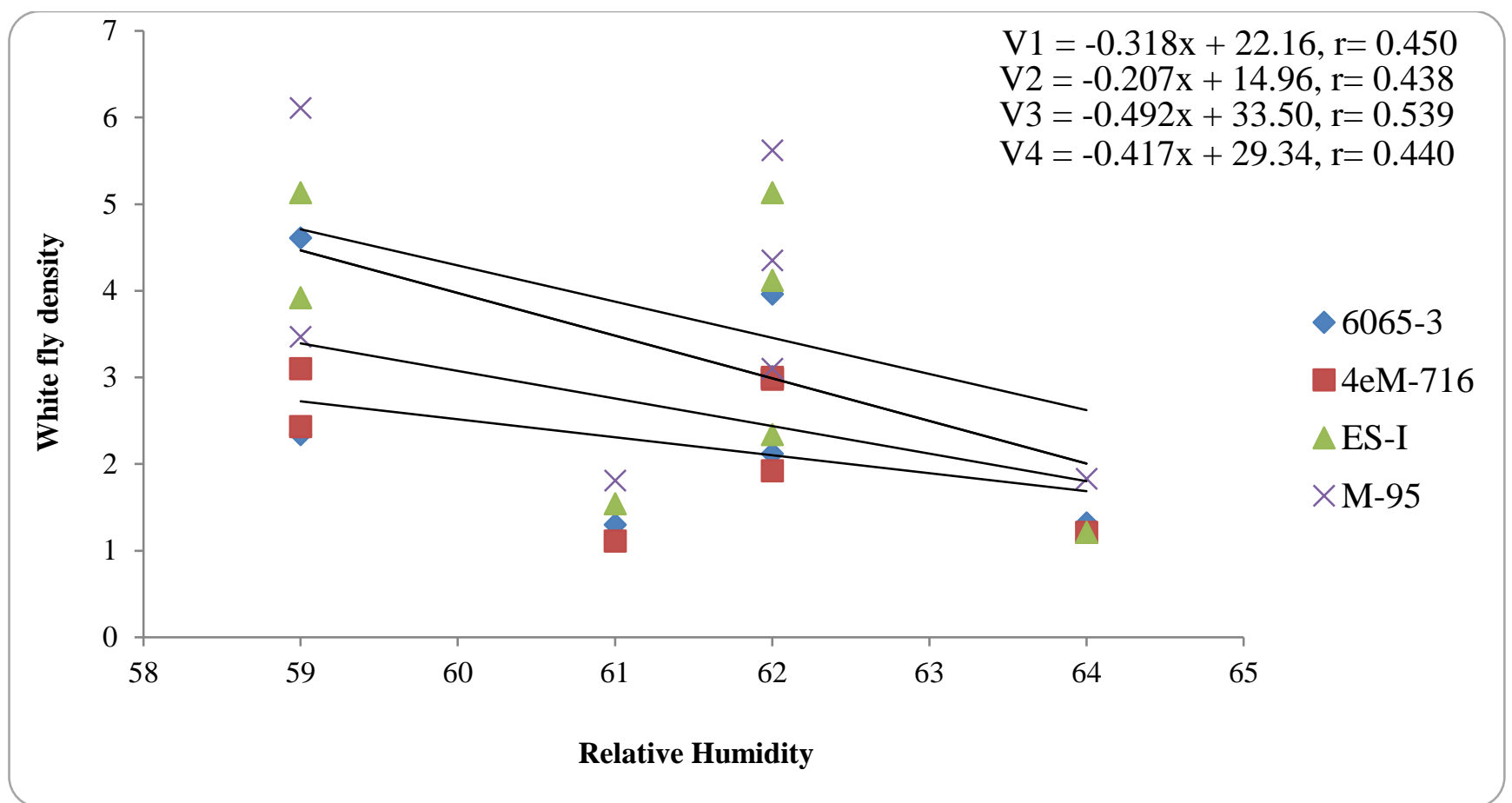

Figure 4. Relationship of relative humidity with whitefly density recorded on urdbean genotypes

Effect of ULCV on the physiology of urd bean ranging from 12.3-24.4ug/g than healthy plants. Among the genotypes infected varieties, the chlorophyll content was found higher

Total Chlorophyll contents: The results showed that total in Arooj followed by ARRIM-08 whereas minimum chlorophyll contents were abundant in all the infected plants chlorophyll content was found 6036-21 (Figure 5).

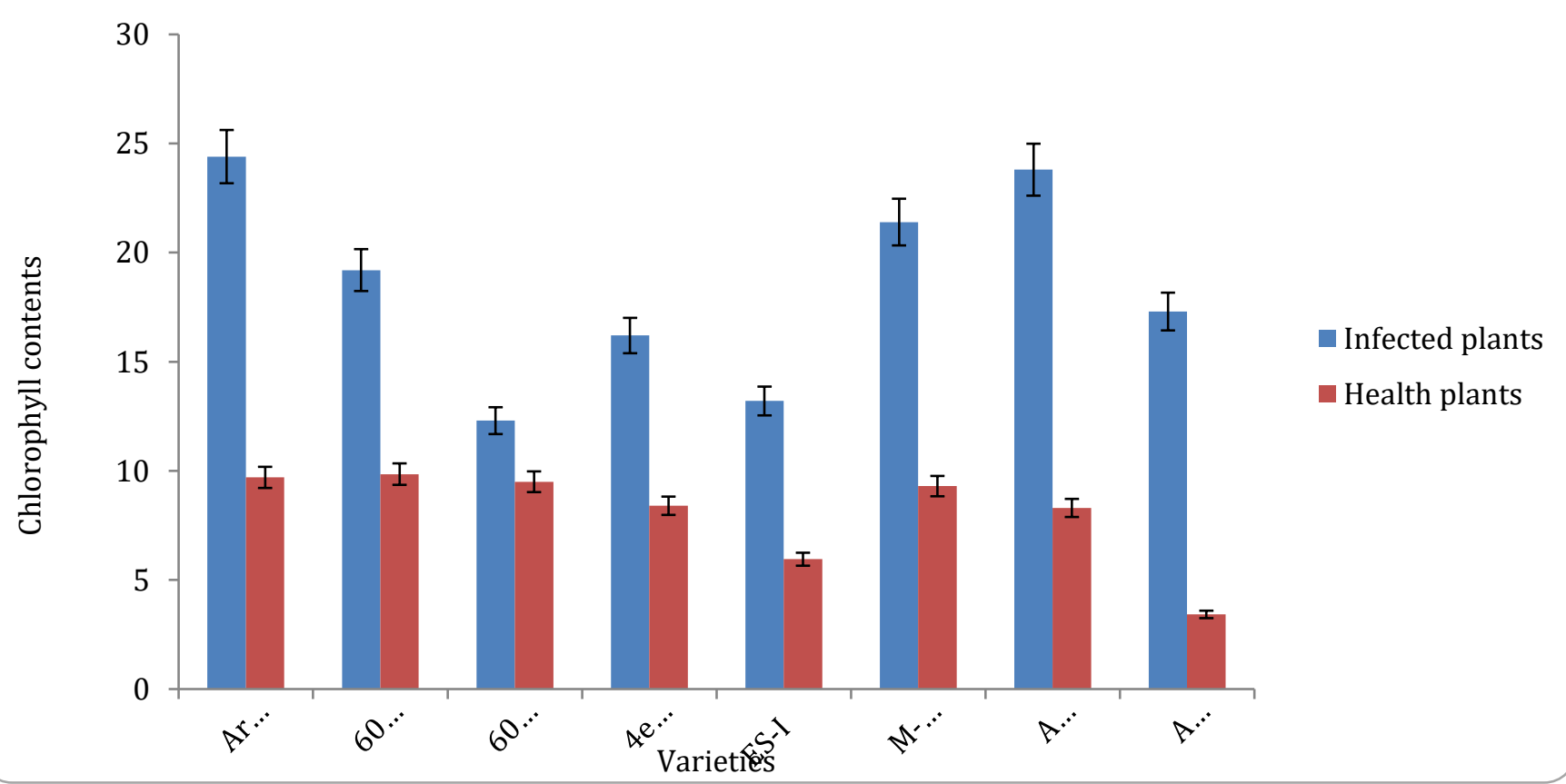

Figure 5. Comparison of chlorophyll contents between infected and healthy urdbean genotypes

Photosynthetic rate: In case of photosynthetic rate, significant increase was recorded in different urdbean genotypes. The total mean of photosynthetic rate of 5.36 (4.36-8.97) was higher as compared to healthy plants with a total mean 2.20 (1.42-2.95) (Figure 6). 


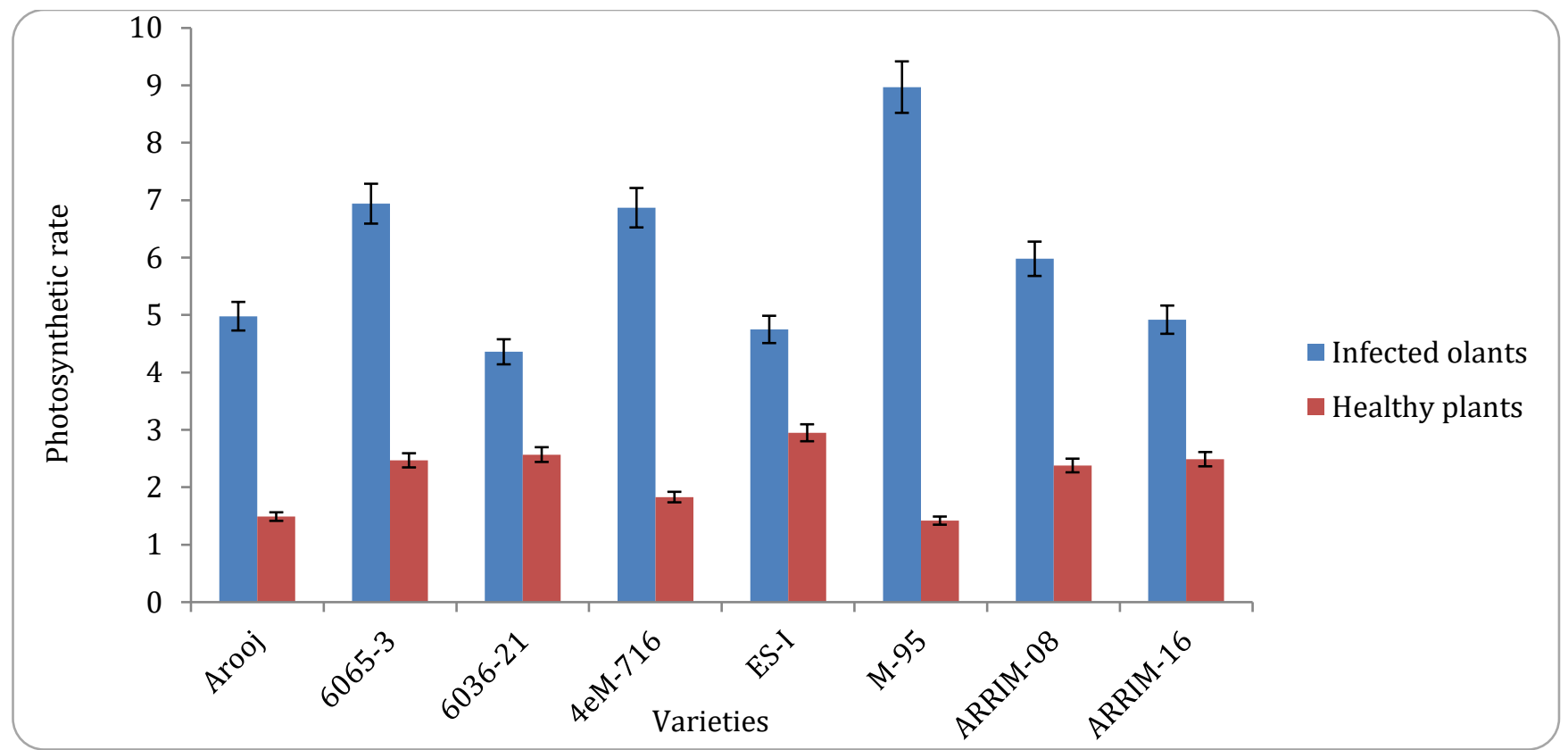

Figure 6. Comparison of photosynthetic rate between infected and healthy urdbean genotypes

Total soluble phenols: The total soluble phenols were the healthy genotypes. The mean of total soluble phenols recorded high in both healthy and infected plants. Significant increase in the total soluble phenol was recorded. The total soluble phenol contents of susceptible was 82.19 (74.32-85.18) $\mathrm{mg} / \mathrm{kg}$ fresh weight in healthy plants, which increased to 102.5 (94.2-111.5) $\mathrm{mg} / \mathrm{kg}$ fresh weight in infected plants of susceptible genotypes after urdbean genotypes were found to be high as compared to the ULCV infection (Figure 7).

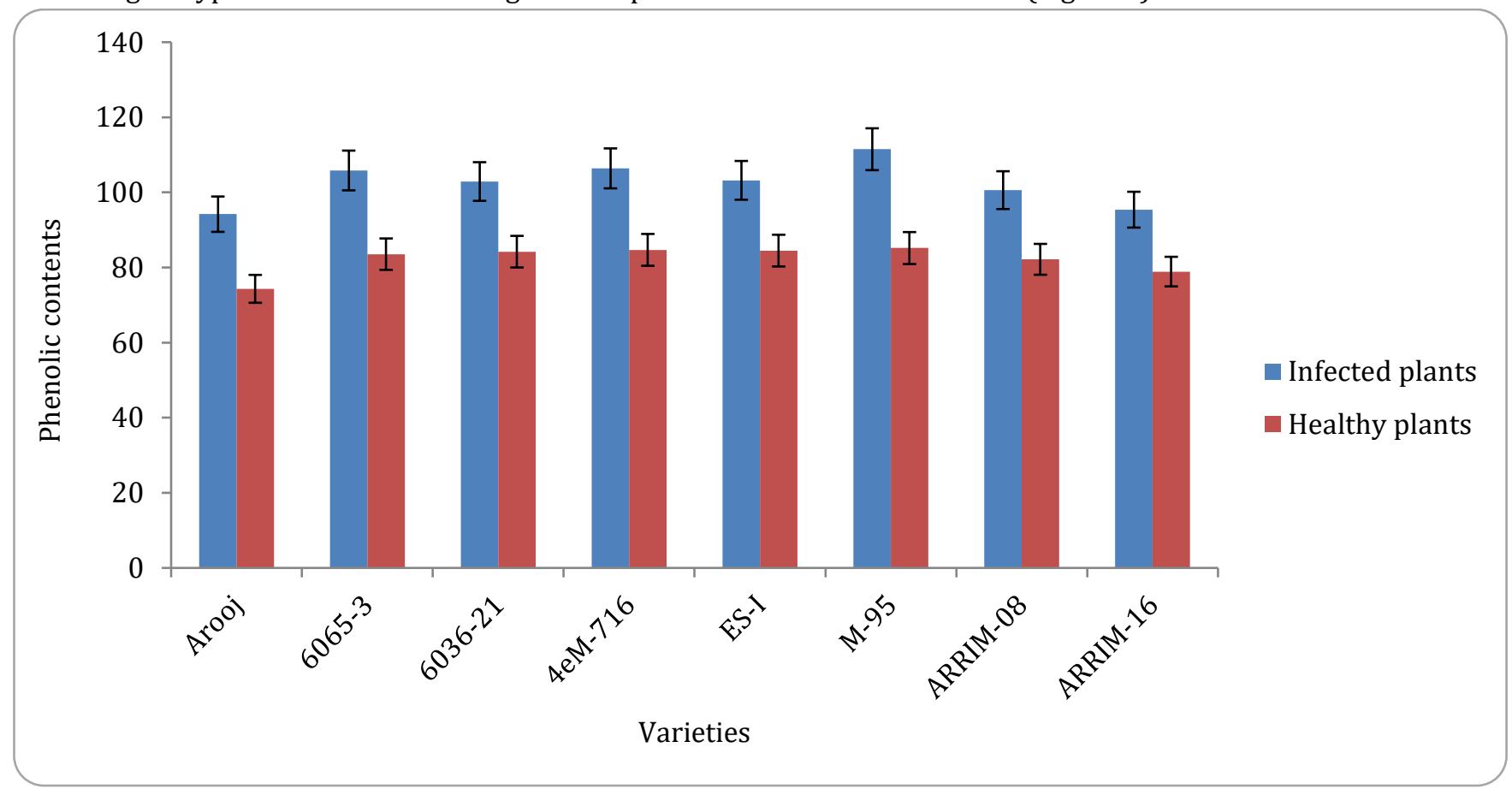

Figure 7. Comparison of total phenol between infected and healthy urdbean genotypes

\section{DISCUSSION}

Urdbean leaf crinkle virus (ULCV) is one of the major, common, and most destructive diseases of the urd bean genotypes in Pakistan and other countries.
High morbidity was recorded annually and is played by a combination of factors such as inoculation, appropriate environmental conditions, and high whitefly density. Eight urdbean genotype tests were 
carried out on ULCV in the fields of Sargodha. The severity of the disease and its progression are checked weekly until the maximum amount of infection is reached. All conditions in Sargodha seem well suited to the spread and development of infection. The whitefly (Bemisia tabaci) is considered a carrier of ULCV and is monitored throughout the trial. The whitefly density range was at 2-8 adults. Only one genotype (Arooj) is resistant, three genotypes (6036-21, ARRIM-08, ARRIM-16) are moderately resistant, three genotypes (6065-3, 4em716, ES-I) are moderately sensitive, and only one genotype (M-95) was severely infected. Our results are similar to the results from Ashfaq et al., (2007), who observed a large number of urdbean infected by ULCV and showed strong resistance to certain genotypes. Bashir et al. (2006) reported that ULCV infections were very low due to low population and satisfactory rainfall during the same season. The results show that under the pressure of viruses and vectors, the genotype resistance is reduced. The overall results Rahioui et al. (2013) associated with ULCV disease were associated with an increase in total rapid phenolic contents caused by ULCV infection. The total amount of phenol present in the healthy urdbean genotypes was much smaller than the total amount of liquid phenol present in infected urdbean genotypes. In the healthy plants, the total phenol content was $82.19 \mathrm{mg} / \mathrm{kg}$ of fresh weight and in ULCV infected plants, the total phenol contents weight increased to $102 \mathrm{mg} / \mathrm{kg}$. This study found that the average increase in the total amount of chlorophyll contents on the infected plant was significantly different from the average increase in healthy plants of 18.47 and 8.05. The total amount of chlorophyll contents in the plants infected with ULCV increased significantly. Our results are in agreement, with the Brar and Rataul (1986) and Ashfaq et al. (2014), which reported that chlorophyll contents have significantly increased on the infected urdbean genotypes. Epidemiological factors leading to the spread and development of urdbean leaf disease were examined under the ubiquitous field conditions. Temperature plays an important role in the development of disease in environmental factors. The results showed that there was no significant correlation between genotype disease and maximum temperature. The highest and lowest temperatures had a negative impact on the urdbean genotype, with the result that there was a disagreement with the study of Ashfaq et al. (2008). They concluded that the maximum temperature was positively correlated with the virus infection. At low temperatures, the disease did not increase in all urdbean genotypes. Our results are consistent with Ashfaq et al. (2008) results that the relative humidity has no significant effect on the development of the disease. They found no relationship between relative humidity and the number of whiteflies and the incidence of the disease.

\section{CONCLUSION AND FUTURE RECOMMENDATIONS}

All the tested genotypes showed a susceptible response to ULCV. The population density of the whiteflies was positively correlated with the ULCV. The biochemical changes and compounds were higher in the infected plants as compared to healthy plants. The environmental factors were positively correlated with the ULCV. More research is required to properly distinguish and characterize ULCV based on the serological, molecular and biological methods.

\section{ACKNOWLEDGEMENT}

The authors are highly Acknowledge to Department of Plant Pathology, College of Agriculture, University of Sargodha for providing research space.

\section{REFERENCES}

Arooj, S., Y. Iftekhar, M. Mubeen, M. I. Ullah, A. Sajid, S. Ali, Q. Shakeel, M. Aatif, W. Raza and I. R. Noorka. 2019. Effect of environmental factors on biochemical properties of tomato leaf curl virus infected leaves of tomato. Pakistan Journal of Phytopathology, 31: 105-111.

Ashfaq, M., M. A. Khan and N. Javed. 2008. Characterization of environmental factors conducive for urd bean leaf crinkle (ULCV) disease development. Pakistan Journal of Botany, 40: 26452653.

Ashfaq, M., M. A. Khan, N. Javed, S. Mughal, M. Shahid and S. Sahi. 2010. Effect of urd bean leaf crinkle virus infection on total soluble protein and antioxidant enzymes in black gram plants. Pakistan Journal of Botany, 42: 447-454.

Ashfaq, M., M. A. Khan, S. Mughal, N. Javed, T. Mukhtar and M. Bashir. 2007. Evaluation of urd bean germplasm for resistance against urd bean leaf crinkle virus. Pakistan Journal of Botany, 39: 2103-2111.

Ashfaq, M., M. A. Khan, T. Mukhtar and S. T. Sahi. 2014. 
Role of mineral metabolism and some physiological factors in resistance against urd bean leaf crinkle virus in black gram genotypes. International Journal of Agriculture and Biology, 16: 189-194.

Bashir, M., S. Mughal and B. Malik. 1991. Assessment of yield losses due to leaf crinkle virus in urd bean (Vigna mungo (L) Hepper). Pakistan Journal of Botany, 23: 140-142.

Bashir, M., Z. Ahmad and S. Mansoor. 2006. Occurrence and distribution of viral diseases of mung bean and mash bean in Punjab, Pakistan. Pakistan journal of botany, 38: 1341-1351.

Bhaktavatsalam, G., Y. Nene and S. Beniwal. 1983. Influence of certain physico-chemical factors on the infectivity and stability of urd bean leaf crinkle virus. Indian Phytopathology, 36: 489-493.

Bhardwaj, S. and G. Dubey. 1986. Studies on the relationship of urd bean leaf crinkle virus and its vectors, Aphis craccivora and Acyrthosiphon pisum. Journal of Phytopathology, 115: 83-88.

Binyamin, R., M. A. Khan, N. Ahmad and A. Safdar. 2011. Relationship of epidemiological factors with urd bean leaf crinkle virus disease and its management using plant extracts. International Journal of Agriculture and Biology, 13: 411-414.

Brar, J. and H. Rataul. 1986. Some field characteristics of leaf crinkle virus of urd bean, Vigna mungo (L.) Hepper. Indian Journal of Virology, 2: 49-56.

Chaovanalikit, A. and R. Wrolstad. 2004. Total anthocyanins and total phenolics of fresh and processed cherries and their antioxidant properties. Journal of food science, 69: FCT67FCT72.

Chohan, J.S. and H.R. Kalia. 1972. Viral diseases of Phaseolusmungo $\mathrm{L}$ and their control through resistant varieties. Proceeding International pulse workshop conference IARI. New Delhi: 65-67.

Ilyas, M., M. Haq and K. Iftikhar. 1992. Studies on the responses of growth components of urd bean against leaf crinkle virus. Pak Phytopathology, 4: 51-56.

Kadian, O. P. 1980. Studies on leaf crinkle disease of urd bean (Vigna mungo (L.) Hepper)/mung bean (Vigna radiata (L.) Wilczek) and its control. College of Agriculture.

Luria, S.E., J.R. Darnell, D. Baltimore and A. Campbell. 1978. General Virology. John Wiley and Sons, New York, USA.

Montasser, M. S., F. D. Al-Own, A. M. Haneif and M. Afzal. 2012. Effect of Tomato yellow leaf curl bigeminy virus (TYLCV) infection on tomato cell ultrastructure and physiology. Canadian Journal of Plant Pathology, 34: 114-125.

Mubeen, M., Y. Iftikhar, M. I. Ullah, Q. Shakeel, M. Aatif and I. Bilqees. 2017. Incidence of Okra Yellow Vein Mosaic disease in relation to insect vector and environmental factors. Environment \& Ecology, 35: 2215-2220.

Nene, Y. 1972. A survey of viral diseases of pulse crops in Uttar Pradesh. A survey of viral diseases of pulse crops in Uttar Pradesh.

Rahioui, B., S. Aissam, H. Messaouri, A. Moukhli, B. Khadari and C. El Modafar. 2013. Role of Phenolic Metabolism in the Defense of the Olive-tree against Leaf-spot Disease Caused by Spilocaea oleaginae. International Journal of Agriculture and Biology, 15: 273-278.

Ravinder Reddy, C., V. A. Tonapi, S. Varanavasiappan, S. Navi and R. Jayarajan. 2005. Influence of plant age on infection and symptomatological studies on urd bean leaf crinkle virus in urd bean (Vigna mungo). International Journal of Agriculture Sciences, 1: 1-6.

\begin{tabular}{|l}
\hline Contribution of Authors: \\
Yasir Iftikhar \\
Mustansar Mubeen \\
Qaiser Shakeel \\
Hafiz M. A. Saeed \\
Sonum Bashir \\
Ashara Sajid \\
Faheema Bakhtawar \\
Aqleem Abbas \\
Shehzad Iqbal \\
\hline
\end{tabular}

: Designed the experiment and wrote the manuscript

: Prepared figures and help in performing experiment

: Designed the experiment

: Performed the experiment

: Performed the experiment

: Performed the experiment

: Analyzed the data

: Edit the manuscript

: Review manuscript 